\title{
Liquefied Natural Gas as Ship Fuel: A Maltese Regulatory Gap Analysis
}

\author{
Mark Philip Cassara, Dimitrios Dalaklis ${ }^{b}$, Fabio Ballini ${ }^{b}$, \\ Seyedvahid Vakilib
}

With water covering almost three-quarters of the Earth's surface and by factoring in that the maritime transport industry is holding a comparative advantage in relation to all other means, activities associated with the seas and oceans of our planet are extremely vital for a normal functioning of global trade. Furthermore, evaluating the opportunities of the so-called "Blue Economy" and possibilities for further growth should be at the epicentre of future development plans. Indicative examples apart from various endeavours of maritime transport - include other sectors, like shipbuilding and repairs, fishing activities and related processes, as well as oil and gas exploration. All these provide a significant economic output and facilitate job creation.

It is true that the shipping industry contributes to the carriage of vast quantities of cargo and maintains a crucial role in global trade; however, the specific industry is also responsible for significant quantities of greenhouse gas (GHG) emissions. IMO (MEPC) in 2018 adopted an initial strategy on the reduction

\section{KEY WORDS}

$\sim$ Liquefied natural gas

$\sim$ LNG

$\sim$ Malta

$\sim$ Regulation

$\sim$ National legislation

$\sim$ Regulatory gap

a. Transport Malta, Triq Pantar, Malta

e-mail: mark.p.cassar@gmail.com

a. World Maritime University, Malmö, Sweden

e-mail: dd@wmu.se

doi: 10.7225/toms.v10.n01.020

This work is licensed under (cc) BY

Received on: Feb 3, 2021 / Revised on: Apr 5, 2021 / Accepted on: Apr 11, 2021 / Published: Apr 20, 2021 of GHG emissions from ships. This plan envisages a reduction of $\mathrm{CO}_{2}$ emissions per transport work, at least $40 \%$ by 2030 , pursuing efforts towards an even further reduction by 2050, compared to the 2008 levels. It is imperative for shipping and related industries to investigate and introduce more environmentally friendly ("cleaner") ways of operation. In the search for these cleaner fuels, it is the responsibility of maritime stakeholders to make available (economically viable) fuel alternatives worldwide.

In view of an increasing trend in using Liquefied Natural Gas (LNG) as a marine fuel, setting up regulations and amend national legislation to allow the provision of LNG as a ship fuel in a safe manner, is a first stage which potential service providing countries have to successfully fulfil. The current analysis is focusing on the small island state of Malta, which, apart from certain international aspects introduced by the International Maritime Organisation (IMO), it has to abide under European Union's (EU) regulations, making LNG as a marine fuel available until 2025. Its main aim is to provide ways to cover the identified regulatory gap of the Maltese legislation, relating to ports, ship fuel bunkering, and the local gas market.

\section{INTRODUCTION}

The contemporary globalized world is characterized by intensive interactions between nations and the maritime industry is very often termed as the "servant of international trade" (Dalaklis, 2017). The world seaborne trade is expected to grow by a factor of $2.5 \%$ from 2020 to 2040 (Schröder-Hinrichs et al., 2018); if appropriate mitigation measures are not taken, the negative impacts of international shipping would only be enhanced (Ölçer et al., 2018). The maritime transport industry is indeed serving about $80 \%$ of global trade (UNCTAD, 2019), at the same time producing a noteworthy quantity of global $\mathrm{CO}_{2}$ emissions, as estimated between 2007 and 2012 by the Third 
International Maritime Organisation (IMO) Greenhouse Gas Study, 2014. By adopting an initial strategy framework in reduction of GHG emissions from ships, as well as by introducing a Data Collection System (DCS), along with the European Union (EU) which has introduced a Monitoring, Reporting, and Verification (MRV) regulation scheme, the IMO have created a worldwide approach towards effectively monitoring and reducing the GHG effect (Nikitakos et al., 2018). Fuels with a "greener environmental footprint", like Liquefied Natural Gas (LNG), are also part of a similar effort.

Malta has been chosen as the focus of this research paper. Regarding demand and supply - since it is a small Island nation - the setting up of an infrastructure is quite a challenging issue. From the regulatory perspective, being an EU member state, Malta has to be able to provide LNG as a marine fuel by 2025 (2014/94/EU, 2014). This requires that should Malta follow the EU directives, while amending its national legislation to be in line with the new infrastructure needed to supply LNG fuel for both local and international shipping. Since 2017, supplying LNG from a floating storage unit (FSU) to an electrical power generation plant in Delimara, is already in progress. In 2018 Malta initiated the installation of a gas pipeline to connect the island to the European grid. This project is expected to be accomplished by 2024 ("SNAM RETE GAS", 2017). Malta is into a study phase of the provision of LNG for ship fuel, following a more generic study which was carried out in 2015 for a potential demand which is expected after the regulations come into force in 2020 (CT3017/2017, 2017).

In this paper a detailed review of international regulations and EU directives which Malta has to abide by is provided, along with the associated national legislation. Additionally, results from a regulatory gap analysis will be discussed. Section 2 will provide details on international regulations and directives which are the foundation of setting up the LNG infrastructure, together with the perspective of what has already been done in the Baltic and the Mediterranean regions. Section 3 will analyse the documents related to the LNG bunkering in Malta and gaps related to LNG bunkering are identified together with the required amendments. Section 4 represents the necessary conclusion and recommendations.

\section{REGULATIONS, DIRECTIVES, AND NATIONAL LEGISLATIONS}

From international regulations to national legislations, there are several documents that need to be taken into consideration, which all relate to the use of LNG as marine fuel. This section presents a literature analysis of international, EU, and national regulations, policies, guidelines, and standards which Malta has, to be in line with, as well as comparative means from the countries already in the LNG market: they are summarised in Figure 1.

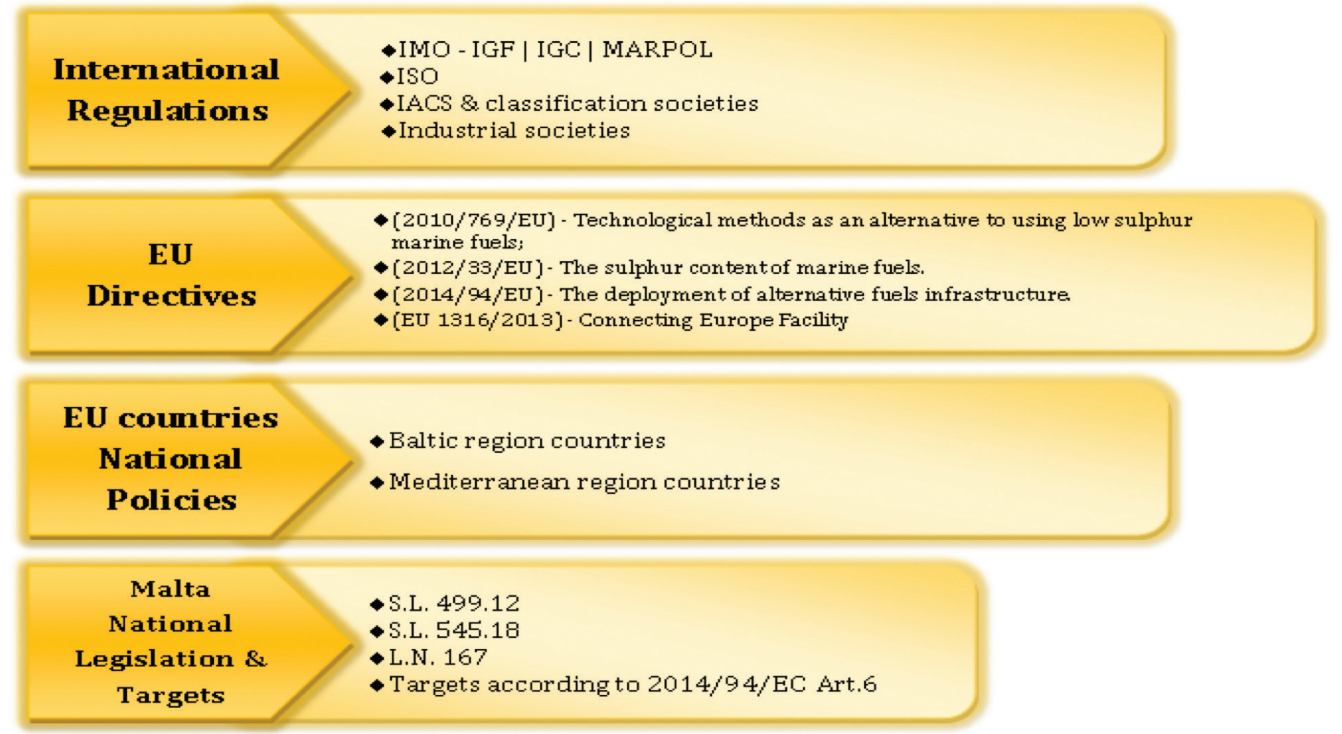

Figure 1.

The documents with effect of LNG bunkering which are analysed in this paper. Source: Authors. 


\subsection{International Regulations}

Various important organizations have already published documentation and guidelines for the use of LNG as a marine fuel. The most influential of them will be discussed in the sections that follow.

\subsubsection{International Maritime Organization}

In relation to LNG, the IMO has a number of conventions and codes which the LNG bunkering ships will have to comply with:

- International Convention for the Safety of Life at Sea (SOLAS);

- International Convention for the Prevention of Pollution from Ships, 1973 as modified by the Protocol of 1978 and amended (MARPOL);
- International convention on Standard of Training, Certification and Watch keeping (STCW);

- Interim Guidelines on Safety for Natural Gas-Fuelled Engine Installations in Ships MSC.285(86);

- International Code for Construction and Equipment of ships Carrying Liquefied Gases in Bulk (IGC code);

- International Code of Safety for Ships using Gases or Other Low Flashpoint Fuels (IGF Code).

With respect to LNG as a marine fuel, the IGC and IGF codes are the most influential ones and describe all the technical details that are necessary to ensure safety during the employment of LNG as a fuel. The regulation of emissions from the combustion of fuels on international ships is associated with the MARPOL Convention and presented on a timeline Figure 2.

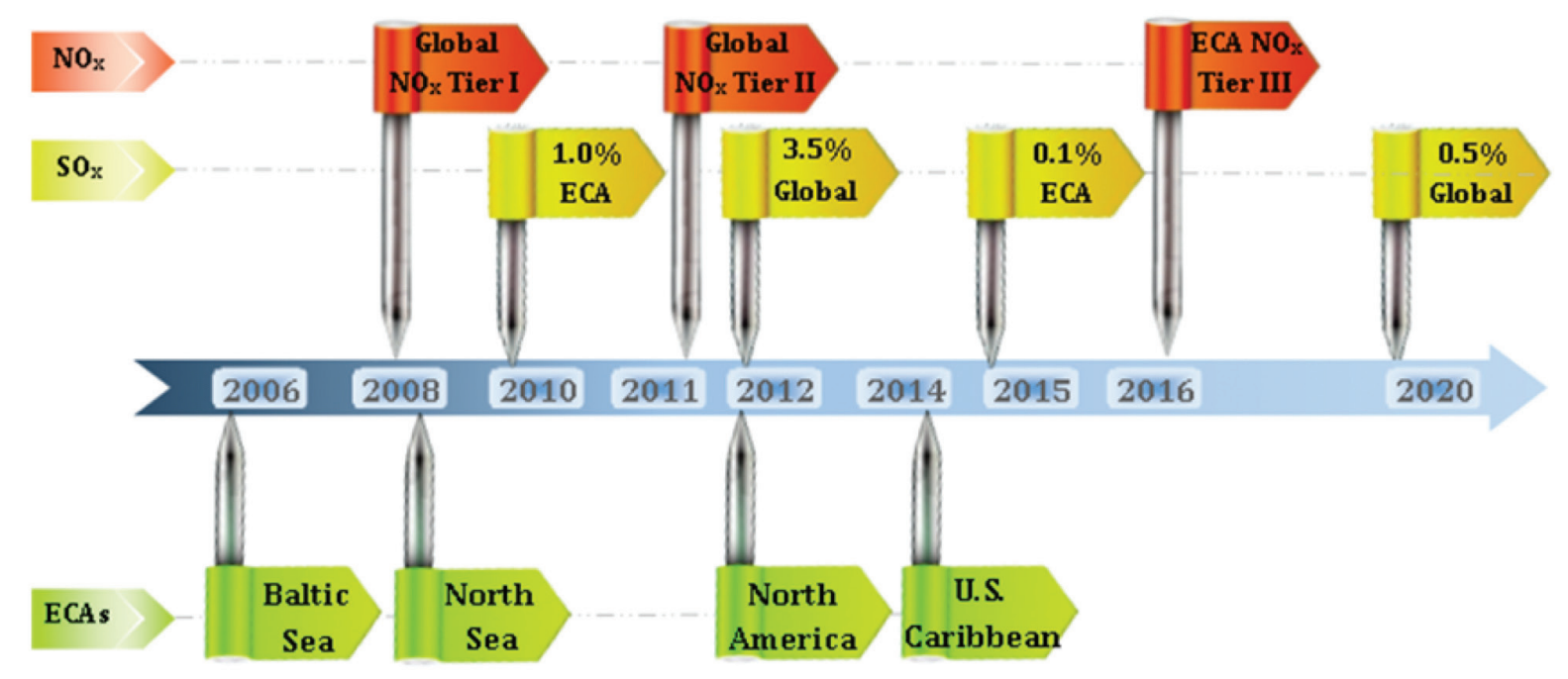

Figure 2.

Targets as set by IMO.

Source: (MARPOL, 2013).

MARPOL Annex VI Reg 13: NOx. Every diesel engine onboard a ship with a power greater than $130 \mathrm{~kW}$ should comply with this regulation, as tabulated below (see Table 1).
MARPOL Annex VI Reg 14: SOx and PM. The level of sulphur content is to be complied with by all ships according to the following limits (see Table 2). 
Table 1.

NOx emission limits as set by the IMO.

Source: (MARPOL, 2013).

\begin{tabular}{llll} 
& Tier I & Tier II & Tier III \\
\hline Ship construction date & $1^{\text {st }}$ Jan $2000-1^{\text {st }}$ Jan 2011 & On or after $1^{\text {st }}$ Jan 2011 & $1^{\text {st }}$ Jan $2016 \&$ in NECA area \\
\hline $\mathrm{n}<130 \mathrm{rpm}$ & $17.0 \mathrm{~g} / \mathrm{kWh}$ & $14.4 \mathrm{~g} / \mathrm{kWh}$ & $3.4 \mathrm{~g} / \mathrm{kWh}$ \\
\hline $130=\mathrm{n}<2000 \mathrm{rpm}$ & $\mathrm{n}^{(-0.2)} \mathrm{g} / \mathrm{kWh}$ & $\mathrm{n}^{(-0.23)} \mathrm{g} / \mathrm{kWh}$ & $\mathrm{n}^{(-0.2)} \mathrm{g} / \mathrm{kWh}$ \\
\hline $\mathrm{n}>2000 \mathrm{rpm}$ & $9.8 \mathrm{~g} / \mathrm{kWh}$ & $7.7 \mathrm{~g} / \mathrm{kWh}$ & $2.0 \mathrm{~g} / \mathrm{kWh}$
\end{tabular}

Table 2 .

SOx emission limits as set by the IMO.

Source: (MARPOL, 2013).

GLOBAL

SECA

\begin{tabular}{llll}
\hline Before $1^{\text {st }} \operatorname{Jan} 2012$ & $4.5 \% \mathrm{~m} / \mathrm{m}$ & Before $1^{\text {st }}$ July 2010 & $1.5 \% \mathrm{~m} / \mathrm{m}$ \\
\hline On and after $1^{\text {st }} \operatorname{Jan} 2012$ & $3.5 \% \mathrm{~m} / \mathrm{m}$ & On and after $1^{\text {st }}$ July 2010 & $1.0 \% \mathrm{~m} / \mathrm{m}$ \\
\hline After $^{\text {st }} 2020$ & $0.5 \% \mathrm{~m} / \mathrm{m}$ & On and after 2015 & $0.1 \% \mathrm{~m} / \mathrm{m}$
\end{tabular}

\subsubsection{International Standards Organization (ISO)}

The ISO has prepared various standards for the use and operation of LNG related equipment and systems.

- $\quad$ ISO 28460:2010 - Installation and equipment for liquefied natural gas - Ship-to-shore interface and port operations.

- ISO/TS 16901:2015 - Guidance on performing risk assessment in the design of onshore LNG installations, including the ship/shore interface.

- ISO/TR 17177:2015 - Guidelines for the marine interfaces of hybrid LNG terminals.

- ISO/TS 18683:2015-Guidelines for systems and installations for supply of LNG as fuel to ships.

- $\quad$ ISO 20519:2017 - Specification for bunkering of liquefied natural gas fuelled vessels.

The most relevant standard document related to LNG bunkering is the ISO 20519. This document was prepared by the technical committee ISO/TC8 'Ship and Marine Technology'. The need for this international regulation was raised by the IMO and BIMCO. The ISO 20519 was designed with the concept of meeting the industry requirements, as seen from the IMO perspective, while supporting the IGF and IGC codes. The main content of this document includes:
- $\quad$ Liquid and vapour transferring systems;

- Operational procedures;

- The provision of LNG bunker delivery notes by the service provider;

- Personnel training and certification requirements; and

- LNG facilities requirements to meet the respective regulations.

\subsubsection{IACS and major classification societies}

IACS acts as a principal technical advisor for the IMO. Its aim is to provide the minimum requirements for classification societies in terms of technical standards, while ensuring that the appropriate safety and environmental protection within the maritime sector are achieved and maintained. For the LNG sector, IACS has published a document 'No. 142 - LNG Bunkering Guidelines'. A few other classification societies have also published documentation/guidance in relation to LNG bunkering. These regulations are to be applied to LNG ships so that they can be certified as safe for operation. Table 3 presents these documents. 
Table 3.

Collection of LNG bunkering related rules/guidelines from classification societies.

Source: (Volsem, 2015).

\begin{tabular}{|c|c|c|c|c|}
\hline Classification Society & Type of Document & Rule Documentation & Reference Code & Publishing Year \\
\hline \multirow[t]{2}{*}{ ABS } & Guide & $\begin{array}{l}\text { LNG Bunkering: Technical and } \\
\text { Operational Advisory }\end{array}$ & n.a. & n.a. \\
\hline & Guide & LNG Bunkering & n.a. & January, 2017 \\
\hline BV & Guide & LNG Bunkering Ship & NR 620 DT R00 E & October, 2015 \\
\hline DNV.GL & Recommended Practice & $\begin{array}{l}\text { Development and operation of liquefied } \\
\text { natural gas bunkering facilities }\end{array}$ & DNVGL-RP-G105 & October, 2015 \\
\hline LR & Rules & Classification of Natural Gas Fuelled Ship & n.a. & January, 2016 \\
\hline \multirow[t]{2}{*}{ PRS } & Rules & $\begin{array}{l}\text { Bunkering Guidelines For LNG as a } \\
\text { Marine Fuel }\end{array}$ & $166 / P$ & March, 2017 \\
\hline & Rules & $\begin{array}{l}\text { Using LNG or Other Low-Flashpoint Fuels } \\
\text { on-board Ships other than Gas Carriers }\end{array}$ & $117 / P$ & March, 2017 \\
\hline RINA & Guide & $\begin{array}{l}\text { Guide for the Design and operation of } \\
\text { Liquefied Natural Gas (LNG) Carriers }\end{array}$ & GUI. 11/E & n.a. \\
\hline
\end{tabular}

\subsubsection{Industrial societies}

There are various other organizations that have published general guidelines for the gas and shipping industry in order to create the awareness and provide standards of operation (Volsem, 2015). Indicative examples are the following: SIGTTO - has published procedures in relation to the ship interfaces and transfer of Cargo LNG; ISGOTT - in collaboration with IAPH has published a handbook with the idea of being a first-hand reference on-board to standardise the procedures of cargo handling between a ship and shore interface; and SGMF - an organization which aims to provide the essential information to all sectors related to LNG bunkering so that the increase in use of LNG for ship fuel can occur smoothly, securely, and safely. Their guide books explain what is essential, spanning from training and competence to contracts, technicality, safety and environmental issues (SGMF, 2016).

\subsection{EU Directives and Regulations}

The EU issues directives (legal documents) in order to set targets for its member states. From a technical point of view, the following directives have been issued with a view to enabling LNG bunkering to achieve its desired effect.

$(2012 / 33 / E U)$ - In this directive the type of fuel used on board ships is restricted by its sulphur content. It sets new sulphur emission limits of $0.1 \%$ from 1st January 2015 for SECA areas. From 1st January 2020 it requires that member states do not allow ships to burn fuel with SOx content of $0.5 \%$ (sulphur cap) or more within their territorial seas and exclusive economic zones. In ports ships are not allowed to burn fuel with SOx content of more than $0.1 \%$. It emphasises that member states are responsible for monitoring and controlling these limits.

(2014/94/EU) - This directive is about provision of various clean fuels on the market. With respect to LNG, it refers to the need of a region-wide infrastructure to make this type of fuel available in an economically effective method. The lack of harmonised standards is consider ed as a barrier to the industry in terms of LNG use. It prescribes creation of LNG bunkering infrastructures such as the TEN-T Core Network. National frameworks are free to make use of the most viable technology according to their needs. Such use of alternative fuels is subject to electricity generation and transport means. Member states are requested to set the targets nationally within their policy framework.

(EU 1316/2013) -This legal document regulates the provision of funds to its member states for conducting feasibility studies and the establishment of the required infrastructure for creating the infrastructure required to provide cleaner and more efficient transport within the European region. From the maritime point of view, it considers the setting up of LNG terminals for the supply of fuel and the provision of electrical shore supply. It also specifies that, as from 1st January 2020, sulphur content in marine fuels should be less than $0.5 \%$ within territorial seas, exclusive economic zones, and pollution control zones. 


\subsection{EU Countries' National Frameworks and Guidelines}

Many studies have been conducted in collaboration with neighbouring countries, with an aim to benefit from one another's knowledge and experiences in different aspects. This can be seen clearly in northern European countries and the Baltic region. In this region the concept of using LNG bunkering in the maritime industry has been developed from scratch because of the stricter regulations of the SECA.

The Rhine inland water region is another example of a collaboration between regions where maritime inland transport is essential. The main outcomes of the LNG Masterplan project in this case have been the analyses of newly built LNG vessels, infrastructure CBA, and regulatory analyses.

In the southern European region, LNG bunkering is in its early stage. Various studies have been conducted which initiated small pilot infrastructural projects. The Poseidon and the COSTA studies provide the core information available for the Mediterranean region. Valencia and Portugal are also being engaged in similar studies, such as the Core LNG as Hive. The aim is to create an infrastructure connecting the North Atlantic with the western Mediterranean, while the eastern Mediterranean is studied in the Poseidon project. For these countries to be in a position to develop such LNG bunkering infrastructures, regulatory analysis must be carried out, and a National Policy framework regarding LNG provision as a marine fuel created. The following sub-sections explore how countries advanced in the LNG sector have prepared for the safe implementation of LNG bunkering in the maritime field.

\subsection{Baltic Region Countries Framework and Guidelines}

Since the Baltic region was selected as a SECA area in 2006, there has been an increased in the investment in alternative fuels, especially LNG (Madjidian et al., 2018). Norway is the leading producer of natural gas in the region. In 2007 Norway inaugurated its first export terminal. As the country increases its exploration for gas offshore, the preferred transportation method is by ship. Following Norway, other Baltic countries have also shown interest in introducing an LNG bunkering infrastructure. Studies have been conducted and have determined the best practice for SECA areas and inland waterways. Various countries have collaborated region-wide and created research groups. The Danish Maritime Authority (DMA) has performed an intensive study on the region-wide infrastructure from the point of view of regulatory and industry standards. This has been followed by a full report on the cost and actual LNG fuelled vessels, as well as different modes of bunkering. The Motorways of the Seas have carried out a series of studies, which have analysed different exhaust abatement methods and a pilot project related to LNG.
Belgium, Sweden and Germany were the first countries to develop port regulations for their respective commercial ports for the use of LNG. Hamburg, Rotterdam, Belgian ports, Zeebrugge, Gothenburg, and Stockholm were the first ports supplying LNG. Other countries like France, Denmark, the Netherlands, Poland, and the UK have followed with investments in LNG infrastructure.

Every member state had its own process to acquire the required permits for their designated LNG infrastructure, and while some chose to install a few large-scale LNG plants, others opted for small-scale projects. Differences in the permit process vary with each country, ranging from one to four years. A bottleneck leading to longer permit approval is the multiple authorities involved in certifying the project. Familiarity with LNG and its technology also plays an important part in the process of approval (Volsem, 2015). The Baltic Sea region project 'Go LNG' is a region-wide project based on principles of sharing of knowledge, which provides information on different aspects of the LNG industry in different countries. It grew out of the startup and increase of LNG use in the Baltic and North Sea region (Dalaklis, Ölçer, Madjidian, Ballini, \& Kitada, 2017).

\subsection{Mediterranean Countries}

Only a few Mediterranean countries have started to analyse deeply on the potential of LNG for bunkering ships. Spain and Portugal are currently investing in the infrastructure, while Italy and Cyprus are conducting feasibility studies. Greece is already operating a limited number of local ferries on LNG.

The GoLNG project (Madjidian et al., 2018) and a project conducted under the TEN-T EU Programme, named COSTA $\left(\mathrm{CO}_{2}\right.$ \& other Ship Transport Emission Abatement by LNG), have provided a better picture regarding the advantages and size of service that might be ideal for the current market. The projects have revealed that LNG is an ideal alternative fuel for short-sea shipping in the Mediterranean region. Following the results of COSTA Projects, Italy has included into its national policy framework the use of LNG as a fuel, as it has a number of fixed short routes of this type. Demand values have been identified to help determine what kind of infrastructure is required. The aim of the study was to analyse the potential short term market on the local maritime transportation, with a prospective increase in demand after 2020, when the regulations are to come into force.

In Italy the use of fixed LNG bunkering stations and the use of truck bunkering are seen as the ideal infrastructure to reach up to medium sized provision. The analysis of the ports ideal to have the infrastructure is underway. This analysis is based on investments required, the space for infrastructure, and a possible demand increase in the coming years (Laviola et al., 2018), and it spans various major ports around the Italian Peninsula. 
In order to initiate a demand for LNG, ships need to run on LNG. The national policy in Italy explains that focusing on the local market in the short term requires the local fleet to switch to LNG operated ships. ("Decreto Legislattivo", 2017).

Through the Core LNGas Hive project, Spain and Portugal are collaborating to extend the LNG supply chain to the shipping industry. With both the authorities and the industry coordinating the respective studies, the plan is to have the infrastructure up and running by 2020. With fourteen studies, they plan to obtain the knowledge and information required to set up the procedures and national policy frameworks, and to secure the required accreditations. Eleven studies are targeted to analyse the physical implementation, ending the results with pilot infrastructure ("Core LNGas hive", 2016).

The Poseidon MED project, which has been carried out in two stages, has given an initial perspective to the use of LNG as shipping fuel in the eastern Mediterranean region. In Cyprus, partly due to its location close to the Suez Canal entrance, the LNG bunkering is a potential service. Cypriot maritime authorities and private investors are developing infrastructure plans with potential promotion in the near future (Demetriades, 2017).

\subsection{Malta National Legislation and Targets}

In the Maltese Islands and the waters under their jurisdiction, affairs related to maritime terminals, their facilities, and ship bunkering, are regulated under the Subsidiary Legislation (S.L.)499.12: Dangerous cargo ships, marine terminals and facilities, and bunkering regulations. The use of fuels in Malta is regulated by the S.L.545.18: Quality of fuels regulations. The legislation stipulates the ISO standards for the processing of fuels to reach the necessary quality. Specifications of emissions from fuels are also indicated. Emission abatement technologies are mentioned, while suppliers and sampling methods are also regulated. LNG as fuel has already been included, since LNG is used as fuel in Malta's main power generation plant.
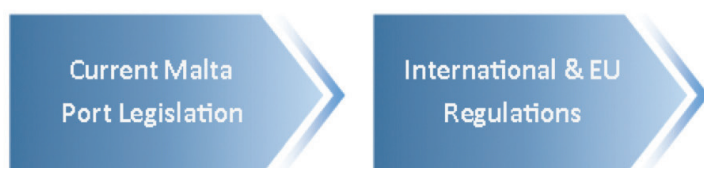

S.L.423.21: Natural gas market regulations specify details for the storage, distribution, supply and operation of natural gas, as transposed from the EU directive 73/2009/EC.

The national targets for the provision of alternative fuels in Malta are in accordance with EU directive 2014/94/EC (CT3017/2017, 2017). Article 6 of this directive specifies: the number of available fuelling points; available infrastructure to meet the market demand; that LNG bunkering infrastructure should be operational by the end of 2025; that LNG distribution system, including loading facilities, should be appropriate; and that after 2020 the Compressed Natural Gas (CNG) should be made available to the public for use as fuel to motor vehicles.

\section{REGULATORY GAP DESCRIPTION}

With the introduction of new technology and its evolution, a regulatory framework is becoming outdated. Application of new technologies requires amendments in the regulations to remove loop holes and have a legally accepted system. The scope of a regulatory gap analysis is to figure out the necessary changes in the current legislation and amend regarding the new requirements (Wheeler, 2015). The focus of this paper is to reveal what documentation is necessary for the implementation of an LNG bunkering infrastructure in Malta. The Maltese legislation is analysed with regard to ship bunkering (S.L. 499.12), and this study points out what needs to be amended in order to facilitate the implementation and use of LNG bunkering practice. The opinions listed are based on other legislations from countries in which LNG bunkering is already available. As a member of the EU, Malta has to comply with the EU directives. The regulatory gap analysis considers the main directives Malta is expected to adhere to, and others that need to be observed in the implementation stages because of environmental issues. The second part of the gap analysis examines aspects essential to the implementation of LNG bunkering infrastructure. These are divided in two sections: the essential port operational procedures set-up and the competence and training required.

Figure 3.

The different stages how the gap analysis was conducted. Source: Authors.

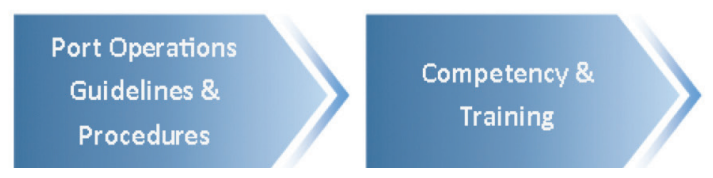


The following literature has been used for the gap analysis: Dangerous Cargo Ships, Marine Terminals and Facilities and Bunkering Regulations. Subsidiary Legislation 499.12. Malta; Quality of Fuels regulations. Subsidiary Legislation 545.18; Natural Gas Market Regulations. S.L.423.21; Liquefied Natural Gas Bunkering Study, published in 2014 by DNVGL; D 4.1.2 \& D 4.1.4 guidelines for port regulations and best practice LNG bunkering. Published in 2015; D 2.3.1 LNG bunkering. Regulatory framework and LNG bunker procedures, published in 2015; Development and operation of liquefied natural gas bunkering facilities (2015); D 3.4.10 legal and regulatory road map (2015); ISO 20519:2017 Ships and marine technology - Specification for bunkering of liquefied natural gas fuelled vessels; Ballini, F. (2013). Air pollution from ships in Danish harbours: Feasibility study of cold-ironing technology in Copenhagen. Italy.

\subsection{Gap Analysis}

Table 4.

Gap analysis of the Maltese legislation in relation to ports and bunkering.

Malta National Legislation and Port Regulations

\begin{tabular}{|c|c|c|}
\hline Current & Gap & Amendment Required \\
\hline $\begin{array}{l}\text { Definition of 'bunker' - "any non-volatile } \\
\text { marine grade fuel oil used to fuel a ship or } \\
\text { its machinery and includes lubricating oil" }\end{array}$ & $\begin{array}{l}\text { The definition of bunker at no point does } \\
\text { it include the gas fuel. Actually it specifies } \\
\text { that bunkers are non-volatile fuel oils. This } \\
\text { means that LNG is not considered as a } \\
\text { marine fuel in Malta. }\end{array}$ & $\begin{array}{l}\text { Amendments to the definition are } \\
\text { needed for the provision of LNG as ship } \\
\text { fuel. }\end{array}$ \\
\hline $\begin{array}{l}\text { Definition of 'Jetty pipeline' - "....substance } \\
\text { could egress into any port or territorial } \\
\text { waters' }\end{array}$ & $\begin{array}{l}\text { LNG release will allow methane as a GHG } \\
\text { gas into the atmosphere. Although no } \\
\text { visible egress, there will be an invisible } \\
\text { GHG impact. }\end{array}$ & $\begin{array}{l}\text { Understand the air pollution cause } \\
\text { by methane slip and include this in } \\
\text { the definition in case of LNG pipeline } \\
\text { damage. }\end{array}$ \\
\hline Missing definition & Definition to be included & 'SGMF','IGF code' \\
\hline $\begin{array}{l}\text { Part III - Bunker supply barges and bunker } \\
\text { receiving ships }\end{array}$ & $\begin{array}{l}\text { The information listed at no point does } \\
\text { it specify the use of LNG bunker vessel. } \\
\text { This is all in relation to oil fuels in terms } \\
\text { of pollution. It is not subject to LNG } \\
\text { bunkering. }\end{array}$ & $\begin{array}{l}\text { The national legislation has to specify the } \\
\text { use of LNG bunker vessel. }\end{array}$ \\
\hline Bunkering checklist & $\begin{array}{l}\text { The legislation does not include checklist } \\
\text { dedicated to LNG bunkering. }\end{array}$ & $\begin{array}{l}\text { All bunkering checklists should include } \\
\text { the appropriate checklists for LNG }\end{array}$ \\
\hline $\begin{array}{l}\text { Legislation is up-to-date including } \\
\text { emission regulations and LNG carriers } \\
\text { making use of Boil off gas. }\end{array}$ & $\begin{array}{l}\text { It does not mention other ships making } \\
\text { use of LNG as marine fuel. }\end{array}$ & $\begin{array}{l}\text { Need to include all ship types using LNG } \\
\text { as fuel. }\end{array}$ \\
\hline $\begin{array}{l}\text { No relation to LNG bunkering service } \\
\text { providers. }\end{array}$ & $\begin{array}{l}\text { This Legal Notice (L.N.) specifies details } \\
\text { for the Natural Gas market in Malta } \\
\text { transposed from EU directive } 73 / 2009 \text {. It } \\
\text { rules the storage, distribution, supply and } \\
\text { operation of natural gas. }\end{array}$ & $\begin{array}{l}\text { Reference to LNG bunkering service } \\
\text { providers required. }\end{array}$ \\
\hline
\end{tabular}


Table 5.

International and EU regulations, and port guidelines gaps for an LNG infrastructure in Malta.

Source: Authors.

LNG Bunkering Regulatory Gap in Malta

\begin{tabular}{|c|c|c|c|}
\hline & Documentation & Gap & Amendment Required \\
\hline \multirow{6}{*}{ 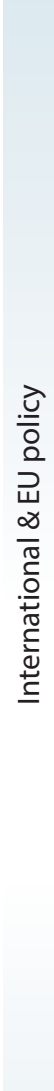 } & $\begin{array}{l}\text { The sulphur content of marine } \\
\text { fuels }(2012 / 33 / E U)\end{array}$ & $\begin{array}{l}\text { As from } 2020 \text { Malta has to } \\
\text { abide to the Sulphur emission } \\
\text { level in ports and territorial } \\
\text { waters }\end{array}$ & \multirow[t]{2}{*}{$\begin{array}{l}\text { By providing a LNG bunkering infrastructure both } \\
\text { in port and for international shipping, Malta will } \\
\text { be providing a clean alternative fuel for local and } \\
\text { international shipping. }\end{array}$} \\
\hline & $\begin{array}{l}\text { The deployment of alternative } \\
\text { fuels infrastructure (2014/94/EU) }\end{array}$ & $\begin{array}{l}\text { Without the implementation } \\
\text { of an LNG bunkering } \\
\text { infrastructure, Malta will not } \\
\text { be giving its full input to the } \\
\text { EU directive in providing } \\
\text { alternative marine fuels. }\end{array}$ & \\
\hline & $\begin{array}{l}\text { Strategic Environmental } \\
\text { Assessment SEA Directive } \\
(2001 / 42 / E C)\end{array}$ & \multicolumn{2}{|c|}{$\begin{array}{l}\text { This directive requires environmental assessment which have to be conducted } \\
\text { when setting up a new plan for the implementation of projects on land and sea. } \\
\text { The aim is to provide a high environment protection. Therefore upon setting up an } \\
\text { LNG bunkering infrastructure within port, these have to be conducted and abide to } \\
\text { accordingly. }\end{array}$} \\
\hline & $\begin{array}{l}\text { IPPC - Industrial Emissions } \\
\text { Directive (2010/75/EU) }\end{array}$ & \multicolumn{2}{|c|}{$\begin{array}{l}\text { The aim of this directive is to control pollution levels from industrial plants. For } \\
\text { such an infrastructure dealing with LNG, the essential tests and certification have to } \\
\text { allow commercial operation. }\end{array}$} \\
\hline & $\begin{array}{l}\text { Environmental Impact } \\
\text { Assessment ElA Directive } \\
(2011 / 92 / E U)\end{array}$ & \multicolumn{2}{|c|}{$\begin{array}{l}\text { This directive applies to both private and public projects which are considered with } \\
\text { possible effect on the environment due to their size and kind of investment. It is up } \\
\text { the national authorities to decide if this directive will be applicable of not. However, } \\
\text { it is expected that a project for an LNG bunkering infrastructure would require such } \\
\text { assessment }\end{array}$} \\
\hline & Seveso II Directive (96/82/EC) & \multicolumn{2}{|c|}{$\begin{array}{l}\text { In order to control the possibility of major accident for a project, this directive } \\
\text { analyse the possible accidents involving hazardous substances. Dealing with } \\
\text { LNG, this directive will be essential for the implementation on LNG bunkering } \\
\text { infrastructure. }\end{array}$} \\
\hline \multirow{5}{*}{ 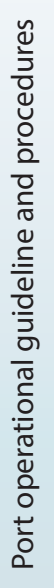 } & $\begin{array}{l}\text { The mode of bunkering ideal } \\
\text { for each port has to be studied } \\
\text { specific to port }\end{array}$ & \multicolumn{2}{|c|}{$\begin{array}{l}\text { Introduce the possible modes of bunkering within the ports of service. This will } \\
\text { include the study of possible storage of LNG demanding on port size and location. } \\
\text { The supply of LNG to the port area will depend on the mode of bunkering chosen. }\end{array}$} \\
\hline & $\begin{array}{l}\text { No information on the risks and } \\
\text { hazard within the Maltese port } \\
\text { harbours }\end{array}$ & \multicolumn{2}{|c|}{$\begin{array}{l}\text { All safety scenario analysis such as HAZID, HAZOP, QRA. Guideline on how these } \\
\text { analysis should be conducted in relation to LNG can be found in ISO/TS 18683/19, } \\
\text { ISO/TS 16901/29 and ISO 20519:2017. }\end{array}$} \\
\hline & $\begin{array}{l}\text { No information for bunkering } \\
\text { zone identification within the } \\
\text { Maltese Harbours }\end{array}$ & \multicolumn{2}{|c|}{$\begin{array}{l}\text { The study and identification of non-specific bunkering zone with ports. This is also } \\
\text { effected by the size of bunker and the mode of bunkering. }\end{array}$} \\
\hline & $\begin{array}{l}\text { Simultaneous operations have } \\
\text { never been considered }\end{array}$ & \multicolumn{2}{|c|}{$\begin{array}{l}\text { SIMOPS requires a case by case analysis depending on which port and what type } \\
\text { of ship is requesting bunkering. Multipurpose ports do require more dedicate } \\
\text { assessments for simultaneous operations. }\end{array}$} \\
\hline & $\begin{array}{l}\text { Emergency plans lack potential } \\
\text { hazards from the use of LNG }\end{array}$ & \multicolumn{2}{|c|}{ Procedures for emergency plans for various type of accidents that might occur. } \\
\hline
\end{tabular}




\begin{tabular}{|c|c|c|}
\hline \multirow{4}{*}{ 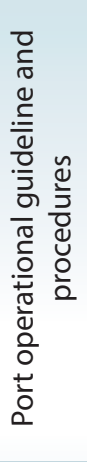 } & $\begin{array}{l}\text { Lack of LNG bunkering service } \\
\text { availability }\end{array}$ & $\begin{array}{l}\text { Accreditation of service providers as per requirements for operators. ISO 18683, } \\
\text { ISO } 20519 \text { and IAPH accreditation model provide guidelines with the terms under } \\
\text { which accreditation is provided }\end{array}$ \\
\hline & Control of Bunkering within port & $\begin{array}{l}\text { Due to multiple operations within the port area, a control system has to be } \\
\text { established to coordinate the port operations and traffic while bunkering. A best } \\
\text { practice guidelines and procedures within ports should be created including the } \\
\text { procedures for different modes of bunkering }\end{array}$ \\
\hline & \multirow[t]{2}{*}{$\begin{array}{l}\text { Possibility of offshore LNG } \\
\text { bunkering Station }\end{array}$} & $\begin{array}{l}\text { Setting up the regulations for safety and procedures for conducting an LNG fuel } \\
\text { transfer on anchor outside port limits but within territorial waters of Malta. }\end{array}$ \\
\hline & & $\begin{array}{l}\text { Such case will require more detailed study in terms of the weather conditions, in } \\
\text { setting up the safe conditions to allow LNG bunkering to take place. }\end{array}$ \\
\hline \multirow{2}{*}{ 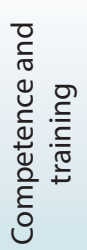 } & \multirow{2}{*}{$\begin{array}{l}\text { No gap is training related to LNG } \\
\text { as this was not in use. However, } \\
\text { with the introduction of LNG } \\
\text { services, the gap for competence } \\
\text { and training will be of much } \\
\text { importance. }\end{array}$} & $\begin{array}{l}\text { Training for operators of LNG bunkering to familiarise and understand the } \\
\text { knowhow and any possible results of mis-use of the LNG system. ISO/TS } 18683 \text { and } \\
\text { ISO 20519:2017 provides training requirements. }\end{array}$ \\
\hline & & $\begin{array}{l}\text { Familiarisation training for port operators for knowledge on how to act in case of } \\
\text { emergency. }\end{array}$ \\
\hline
\end{tabular}

\subsection{Regulatory Gaps Analysis}

The in-depth analysis of Maltese subsidiary legislation in relation to ports and bunkering (S.L.499.12) reveals that, so far, LNG has not been considered as ship fuel. The lack of LNG bunkering provision in Malta is also identified through S.L.423.21, where no reference to LNG bunkering is made in the Maltese markets. The missing definitions are a key factor which indicates that there has been no attempt to have LNG provision in Malta.

The fact that Maltese subsidiary legislation only refers to LNG in S.L.545.18, a section on the quality of fuels, indicates that LNG is already available as a fuel in Malta. However, LNG is only available as fuel for the main electrical power plant in Malta. This shows that amendments to this document were only made with LNG supply for the power plant in mind.

This situation shows that the legislation has been amended to accommodate the current needs. The fact that LNG has not been considered as ship fuel also indicates that this was never part of the legislation. Therefore, one of the first steps that would need to be taken to allow for LNG bunkering in Malta is to amend the legislation legally as suggested in Table 4. Other technical issues related to LNG included in the legislation might require addition of the protection of the environment, including GHGs from the atmosphere and safety related details. The National legislation may also be backed-up by dedicated port bunkering procedures which directly specify issues related to particular situations.

Regulatory gaps in the national legislation are affected by international regulations and, in the case of Malta, EU directives as well. Therefore, gaps also exist in meeting the targets set by the directives. With the introduction of LNG provision as a marine fuel, Malta will be meeting the requirements for the EU directives 2012/33/EU and 2014/94/ EU. This will close the gaps in reaching sulphur emission targets and providing alternative fuels for marine use. The provision of LNG bunkering service would include in-depth studies, risk assessments, third-parties, and major investments.

The implementation of an LNG bunkering infrastructure has to be in line with multiple EU directives. The creation of a shore based or offshore structure has to be compliant with regulations controlling the impact on the environment and safety. Due to the industrial scale of the LNG bunkering infrastructure, plans are assessed to be in line with EU directives as listed in Table 5. All these directives are essential as they control the effect of the infrastructure upon the environment in terms of visual impact, pollution at building, and operational stages. It also assesses the effect on the nearby public, limiting the negative effects of the operation in terms of health and safety matters. The issue with all these directives is that they make the planning and certification process more bureaucratic, as different authorities have to assess the project depending on their control area.

Last but not least, all the regulations need to be provided for the plant operators and area workers for safe and optimum operation. This is done by providing user-friendly guidelines and procedures on what equipment is to be installed and how to operate and maintain the equipment. Safety procedures and limited access by personnel should be clearly identified. A good understanding of such guidelines requires competent training 
friendly and more accessible. Advantages of having LNG as ship fuel should be shown to the local maritime operators in order for them to fully understand the positive effect they can benefit from, while assisting the Maltese ports in reducing their emissions.

As seen in the Baltic region and other Mediterranean countries, vessels operating on LNG have been pushed forward by incentives and collaborative work. It is a must that an initial step should set up the required national regulations and make the LNG available, leading to incentivising the local operators and, in the long run, the international shipping, to increase the trend that, once the regulations and directives come into force, the bunkering infrastructure become available.

\section{NOTICE}

This work is an expanded version of paper presented on Conference DEVPORT 2020: Ports, Transport Maritime et Développement Régional, Le Havre, France, 15 - 16 October 2020.

\section{REFERENCES}

2012/33/EU., 2012. Directive 2012/33/EU of the European parliament and of the council of 21 November 2012 amending council directive 1999/32/EC as regards to the sulphur content of marine fuels.

2014/94/EU., 2014. Directive 2014/94/EU of the European parliament and of the council of 22 October 2014 on the deployment of alternative fuels infrastructure.

COMMISSION DECISION of 13 December 2010 on the establishment of criteria for the use by liquefied natural gas carriers of technological methods as an alternative to using low sulphur marine fuels meeting the requirements of Article $4 \mathrm{~b}$ of Council Directive 1999/32/EC relating to a reduction in the sulphur content of certain liquid fuels as amended by Directive 2005/33/EC of the European Parliament and of the Council on the sulphur content of marine fuels. 2010.

CT3017/2017., 2017. Provision of services for a technical study and cost-benefit analysis for the development of LNG as a marine fuel in Malta.

D 3.4.10 legal and regulatory road map, 2015.

Dalaklis, D., 2017. Safety and Security in Shipping Operations. WMU Studies in Maritime Affairs, pp.197-213. Available at: http://dx.doi.org/10.1007/978-3-319-62365-8_9.

De Ven, M. v., 2015a. D 2.3.1 LNG bunkering. Regulatory framework and LNG bunker procedures.

De Ven, M. v., 2015b. D 4.1.2 \&amp; D 4.1.4 guidelines for port regulations and best practice LNG bunkering. Det Norske Veritas BV.

Development and operation of liquefied natural gas bunkering facilities, 2015. DNVGL.

Ballini, F., 2013. Air pollution from ships in Danish Harbours: Feasibility study of coldironing technology in Copenhagen.

Holden, D., 2014. Liquefied natural gas bunkering study.

International Code for Construction and Equipment of ships Carrying Liquefied Gases in Bulk, 2016. International Maritime Organization.
International Code of safety for Ships Using Gases or Other Low-Flashpoint Fuels, 2016. International Maritime Organization.

ISO/TC 67., 2015, January 13. ISO/TS 18683:2015 Guidelines for systems and installations for supply of LNG as fuel to ships. International Standards Organisation.

ISO/TC 67/SC 9., 2015, June 10. ISO 16903:2015 Petroleum and natural gas industries -- Characteristics of LNG, influencing the design, and material selection. ISO.

ISO/TC 8., 2017, February. ISO 20519:2017 Ships and marine technology Specification for bunkering of liquefied natural gas fuelled vessels. ISO.

ISO/TC67., 2011, June. ISO 22460:2010 Installation and equipment for liquefied natural gas - Ship-to-shore interface and port operations. ISO.

ISO/TR17177., 2015, April 30. ISO/TR 17177:2015 Guidelines for the marine interface of hybrid LNG terminals. ISO.

ISO/TS., 2015, March 31. ISO16901:2015 Guidance on performing risk assessment in the design of onshore LNG installations including the ship/shore interface. ISO.

Laviola, M. et al., 2018. LNG Fueled Barge for Cold Ironing: Feasibility Study for the Emission Abatement in the Port of Genoa. WMU Studies in Maritime Affairs, pp.401413. Available at:

http://dx.doi.org/10.1007/978-3-319-74576-3 28.

L.N.167 - natural gas market regulations, 2011.

Madjidian, J. et al., 2018. Developing a Strategy for Liquefied Natural Gas Powered Transport Corridors in the Baltic Sea Region. WMU Studies in Maritime Affairs, pp.383-399. Available at:

http://dx.doi.org/10.1007/978-3-319-74576-3 27.

MARPOL Consolidated edition, 2011. Articles, protocols, annexes and unified interpretations of the International Convention for the Prevention of Pollution from Ships, 1973, as modified by the 1978 and 1997 protocols. 2011. 5th ed. London: IMO.

MARPOL, 2013. MARPOL: AnnexVI and NTC 2008 with guidelines for implementation. London: International Maritime Organisation.

MSC.285(86) Interim Guidelines on Safety for Natural Gas-Fuelled Engine Installations in Ships;2009. International Maritime Organization.

Nikitakos, N., Dalaklis, D. \& Siousiouras, P., 2018. Real Time Awareness for MRV Data. WMU Studies in Maritime Affairs, pp.53-63. Available at: http://dx.doi.org/10.1007/978-3-319-74576-3 5.

Ölçer, A.I. et al. eds., 2018. Trends and Challenges in Maritime Energy Management. WMU Studies in Maritime Affairs. Available at: http://dx.doi.org/10.1007/978-3-319-74576-3.

REGULATION (EU) No 1316/2013 OF THE EUROPEAN PARLIAMENT AND OF THE COUNCIL of 11 December 2013 establishing the Connecting Europe Facility, amending Regulation (EU) No 913/2010 and repealing Regulations (EC) No 680/2007 and (EC) No 67/2010. 2013.

Schröder-Hinrichs, J.U. et al., 2019. Transport 2040: Automation, Technology, Employment - The Future of Work. Available at: http://dx.doi.org/10.21677/ itf.20190104.

SGMF, 2016. Gas as a marine fuel an introductory guide (2nd ed.) Society of Gas as a Marine Fuel.

S.L.499.12., 2015. Dangerous Cargo Ships, Marine Terminals and Facilities and Bunkering Regulations. Malta.

Smith, T.W.P., et al., 2014. Third IMO Greenhouse Gas Study.London: International Maritime Organization. 
SNAM RETE GAS, 2017. Demand assessment report for incremental capacity between Italy and Malta.

SOLAS: consolidated edition, 2014. Consolidated text of the International Convention for the Safety of Life at Sea, 1974, and its Protocol of 1988: articles, annexes and certificates. 2014. Sixth edition. London: International Maritime Organization.

STCW including 2010 Manila amendments: STCW Convention and STCW Code. 2011. 2011 ed., 3rd consolidated ed. London: International Maritime Organization.

Subsidiary Legislation 545.18 - Quality of Fuels Regulations, 2009.
CT3017/2017, 2017.Provision of services for a technical study and cost-benefit analysis for the development of LNG as a marine fuel in Malta.

United Nation Conference on Trade and Development (UNCTAD), 2019, Review of Maritime Transport, 2019. Retrieved from; https://unctad.org/en/ PublicationsLibrary/rmt2019_en.pdf.

Volsem, S. V., 2015, June 10. LOT 1: Analysis and evaluation of identified gaps and of the remaining aspects for completing an EU-wide framework for maritime LNG distribution, bunkering and use. DNV GL. 